\title{
Optimization of Light Intensity for Olive Propagation under Greenhouse Condition through Semi-Hardwood Cuttings
}

\section{Muhammad Rafique ${ }^{1}$, Muhammad Azhar Iqbal ${ }^{2}$, Inam U1 Haq ${ }^{1 *}$, Muhammad Ramzan Anser ${ }^{2}$, Humara Umar $^{2}$ and Muhammad Ashraf Sumrah ${ }^{2}$}

${ }^{1}$ Barani Agricultural Research Institute (BARI), Chakwal 48800, Pakistan; ${ }^{2}$ Centre of Excellence for Olive Research and Training at BARI Chakwal, Chakwal 48800, Pakistan.

Abstract | Olive cultivation in Pakistan is being commercialized at a fast pace in selected agro-climatic regions. The demand for local plants is increasing and no scientific study has been previously carried out to standardize propagation technology concerning optimization of light intensity under greenhouse conditions. The current study was conducted at Izhar farms (Pvt.) Ltd. under the collaboration with Barani Agricultural Research Institute (BARI) Chakwal to find out the appropriate light intensity for successful olive propagation under greenhouse conditions. The data regarding days to root initiation, number of roots, root length, days to shifting, rooted cutting percentage and callus percentage were collected under four different treatments. Cutting under the only green net (5944 lux), white net (11428 lux) only upper side white net (8484 lux) and both green and white net (5538). The results were found significant regarding the interaction between varieties and treatments; however, non-significant variation in varieties was found regarding the number of roots, days to root, and days to shift. The important observations regarding the results were found that minimum light intensity delayed the rooting percentage and increased the callus formation while higher light intensity increased mortality with increased root length in both varieties with moderate callus formation. Up to three weeks, there was no root development under all treatments. The cuttings under light intensity (8484 lux) produced more numbers of roots, with early initiation in both varieties. Variation in varietal performance was observed under different treatments however 8000 lux light gave better results in all the parameters.

Received | May 22, 2021; Accepted | August 25, 2021; Published | September 07, 2021

*Correspondence | Inam U1 Haq, Horticulturist; BARI Chakwal 48800, Pakistan; Email: inamulhaq601@gmail.com

Citation | Rafique, M., M.A. Iqbal, I.U. Haq, M.R. Anser, H.Umar and M.A. Sumrah. 2021. Optimization of light intensity for olive propagation under greenhouse condition through semi-hardwood cuttings. Pakistan Journal of Agricultural Research, 34(4): 742-747.

DOI | https://dx.doi.org/10.17582/journal.pjar/2021/34.4.742.747

Keywords | Olive cultivation, Local plants, Rooting parameters, Pakistan, Olive cuttings

\section{Introduction}

$\mathrm{O}$ live (Olea europaea L.) is long-lived and evergreen plant that belongs to the Oleaceae family, that has been originated in the Mediterranean region (Isfendiyaroglu, et al., 2009). The Oleaceae family contains about 26 genera and 700 species. Spain, Italy, Turkey, and Greece are the largest producers of olive oil followed by Portugal, Algeria, Tunisia, and Morocco. In addition to the Mediterranean region, olives are also grown in the United States, the Middle East, Australia and Argentina (Seyhan and Gezerel, 2005). The demand for olive sampling has increased in Asian markets due to its vast prospective and climatic adaptability in the region (Mehri, 2009).

There are several asexual propagation methods like budding, grafting cuttings and air layering but propagation through cuttings is considered the easiest and economical method for olive 
multiplication (Dvin et al., 2011; Hartmann et al., 2002). Rooting ability of olive cuttings is subjective to several factors concerning rooting media (Awan et al., 2003; Isfendiyaroglu et al., 2009), cuttings types, olive varieties (Loreti and Hartmann, 1964; Turkoglu and Durmus, 2005), source of cutting material (Ahmed et al., 2002; Sebastiani and Tognetti, 2004) and the growth hormone with its concentration (AslMoshtaghi and Shahsavar, 2011; Hartmann et al., 2002). Light intensity is an important phenomenon for the successful propagation of rooted cuttings. The complementary effects of light intensities on the propagation of many plant species are well understood (Aminah et al., 1997; Currey et al., 2012; Lopez and Runkle, 2008; Park et al., 2011; Zaczek et al., 1997; Zobolo, 2010). The light intensity on the higher side is considered harmful for cuttings, as it increases the transpiration and temperature of the leaf and accelerates the leaf drying of cuttings. The roots of many woody and herbaceous species are affected due to high light (Aminah et al., 1997; Zaczek et al., 1997; Zobolo, 2010). There is a positive correlation between the high light intensities, the number of roots, and length (Currey et al., 2012; Lopez and Runkle, 2008; Park et al., 2011). The light intensity is recommended to keep low in the greenhouse usually to minimize the leaf transpiration and burning effects.

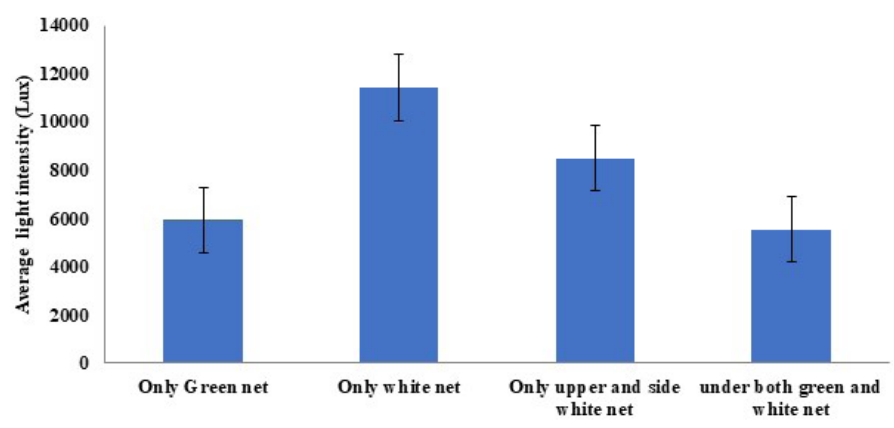

Figure 1: Average light intensities data of all the four treatments during the study.

The cultivation of olive in Pakistan has no longer history however the olive plantation is being increased day by day from the last decade due to its health and economic importance. Olive has been cultivated on more than 5966 acres of land in the Pothwar region (Anonymous, 2018). The results of five olive varieties namely, Gemlik, Nabali, Coratina, Hamdi, and Moraiolo were found satisfactory regarding fruit and oil yield under the environmental conditions of Pothwar, Pakistan (Iqbal et al., 2019). The studies on propagation through cuttings were conducted on a very limit- ed scale regarding the standardization of media, hormonal concentration, varietal behavior, and cutting length and thickness (Hussain et al., 2020; Rehman et al., 2013; Ali et al., 2019) but no study was conducted regarding the standardization of light intensity for successful olive propagation in Pakistan. Hence, the main purpose of the study was to determine the optimum level of light intensity for appropriate rooting under the greenhouse condition.

\section{Materials and Methods}

\section{Experimental location and cutting material}

The research experiment was conducted at "Izhar Farms (Pvt.) Ltd." located in tehsil Kallar Kahar district Chakwal, Pakistan at $460 \mathrm{~m}$ altitude $\left(32^{\circ} 46^{\prime} 33\right.$ $\mathrm{N}$ and $72^{\circ} 4231 \mathrm{E}$ ). The cutting material of two olive varieties (Coratina and Frantoio) was collected from an olive orchard planted with $6 \times 6$ m spacing under a high-efficiency irrigation system at the age of seven years. The semi-hardwood cuttings $(7 \mathrm{~cm}$ in length) were collected with one pair of leaves near the tip and a round cut at the base. Cuttings were treated with IBA (3000ppm) solution for 10 seconds then planted in sand media in bed formation (Figure 2) under greenhouse condition with sprinkler irrigation system controlled by a timer with an interval of every 25 minutes for 10 seconds (day time) in such a way to keep the cuttings wet. The cuttings were planted under four different treatments for variability in light intensities i.e. cutting under the green net $\mathrm{T}_{1}(5944$ lux), white net $\mathrm{T}_{2}$ (11428 lux) upper side, sides white net $\mathrm{T}_{3}$ (8484 lux), and both green and white net $\mathrm{T}_{4}$ (5538 lux)(Figure 1). The temperature inside the greenhouse was maintained at $25( \pm 2)^{\circ} \mathrm{C}$ by heating constantly through the basal heating system. Relative humidity was maintained at 70-80 \% through proper misting. Fungicide spray-applied continuously with a gap of 7 days to prevent the attack of fungus in humid conditions.

\section{Parameters understudy}

The data of days to root initiation was recorded as the first root appeared, length of the root was measured from base to tip of the root, numbers of roots were counted after washing, and after gaining the appropriate root length the numbers of days to shifting were calculated. The percentage of callus formation was counted and the percentage was calculated. The overall success rate was recorded by shifting all the rooted cuttings from sand media to polythene containers. 

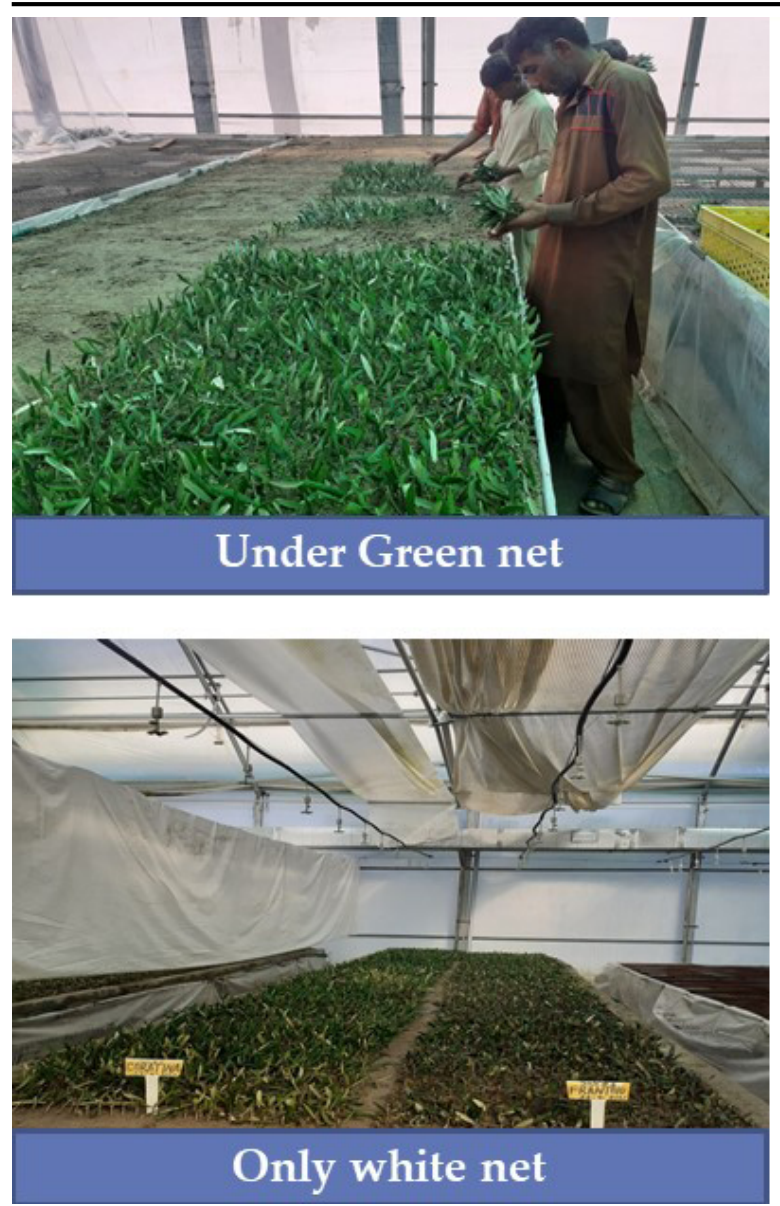
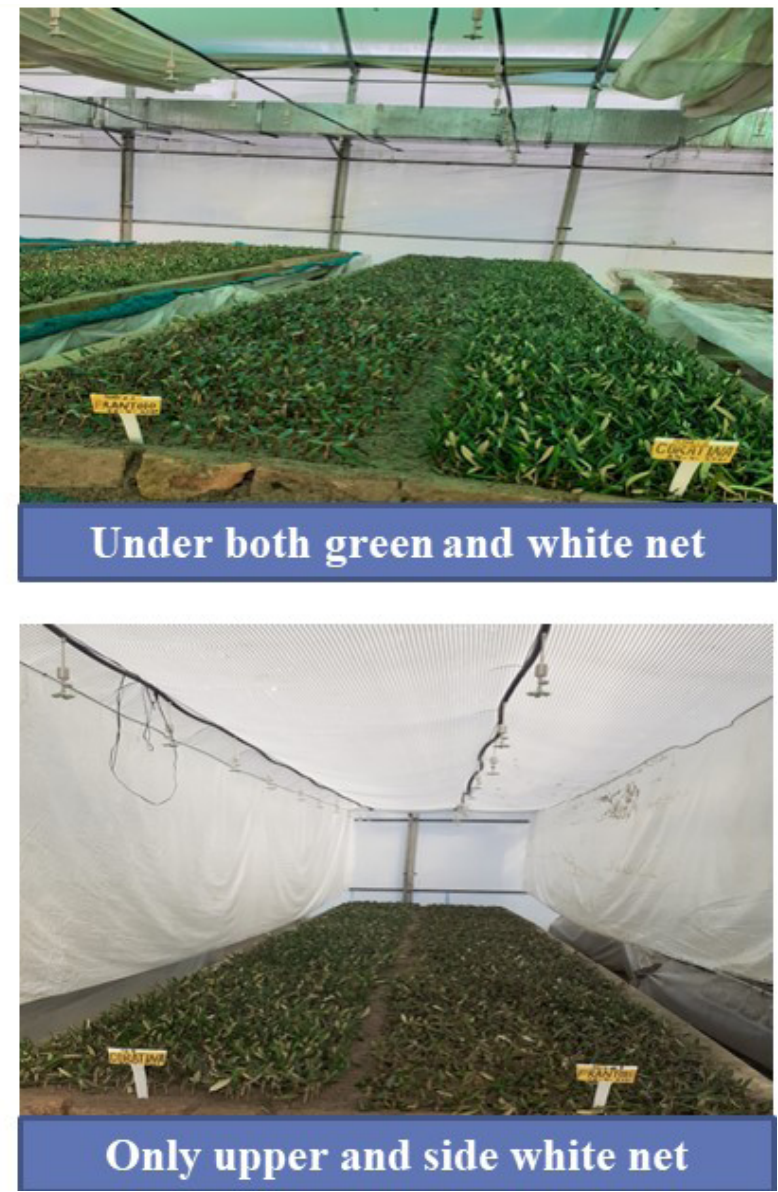

Figure 2: Different light intensities for olive propagation under greenhouse conditions.

The data of temperature, humidity, and light intensity were recorded on daily basis with the help of a hygrometer and lux meter respectively.

\section{Statistical analysis}

The experiment was laid out according to a randomized complete block design with three replications. The data for two varieties with six parameters were analyzed to determine minimum, maximum, means, cumulative variance. The Least Significant Difference (LSD) was utilized to compare the means at $P \leq 0.05$ (Statistics 8.1).

\section{Results and Discussions}

\section{Days to root initiation}

Light intensities varied under various treatments which resulted from the difference in days to root initiation under each treatment. Statistically significant results were found in the treatments while the non-significant result was observed in days to root initiation among varieties. The results presented in the Table 1 showed that both the varieties Frantoio (35.33) and Coratina (33.66) has taken the average maximum number of days for root initiation under
T4 where the average light was 5538 lux while minimum time for root initiation was observed under T3 (8484 lux). Overall T3 was found for better forb early root initiation in both the varieties.

\section{Number of roots}

An analysis of the variance of the results indicated that statistically significant variations were found in the treatments while the non-significant result was observed in between the varieties (Table 1). The maximum average number of roots was recorded under $\mathrm{T}_{3}$ followed by $\mathrm{T}_{2}$ in both varieties. However, Variety Coratina performed better (7.33) than Frantoio (6.66) under $\mathrm{T}_{3}$ and similarly under $\mathrm{T}_{2}$. Both varieties depicted poor performance under $\mathrm{T}_{4}$.

\section{Root length}

The results of root length were significantly affected under different treatments in both varieties (Table $1)$. The overall maximum root length was recorded in the variety of Coratina $(6.89 \mathrm{~cm})$ while the minimum was noted in the variety Frantoio $(5.78 \mathrm{~cm})$. The finding of an interaction between variety and treatment showed that maximum root length was recorded in the variety Coratina $(8.76 \mathrm{~cm})$ under $\mathrm{T}_{2}$ followed by 
Table 1: Impact of varieties and treatments on days to root initiation, number of roots and root length.

Treatments

\begin{tabular}{|c|c|c|c|c|c|c|c|c|c|}
\hline & \multicolumn{2}{|c|}{ Varieties VXT } & \multirow{2}{*}{$\begin{array}{l}\text { Mean } \\
(\mathrm{T})\end{array}$} & \multicolumn{2}{|c|}{ Varieties V XT } & \multirow{2}{*}{$\begin{array}{l}\text { Mean } \\
(\mathrm{T})\end{array}$} & \multicolumn{2}{|c|}{ Varieties VXT } & \multirow{2}{*}{$\begin{array}{l}\text { Mean } \\
(\mathrm{T})\end{array}$} \\
\hline & Coratina & Frantoio & & Coratina & Frantoio & & Coratina & Frantoio & \\
\hline Only green net & $27.33 \mathrm{bc}$ & $29.66 \mathrm{~b}$ & $28.5 \mathrm{~b}$ & $4.66 \mathrm{bc}$ & $4.33 \mathrm{bc}$ & $4.5 \mathrm{~b}$ & $6.36 \mathrm{~b}$ & $5.71 \mathrm{~b}$ & $6.04 \mathrm{~b}$ \\
\hline Only white net & $\begin{array}{l}26.66 \pm \\
1.03 \mathrm{bc}\end{array}$ & $\begin{array}{l}27.66 \pm \\
1.10 \mathrm{bc}\end{array}$ & $27.16 \mathrm{bc}$ & $6 \pm 0.30 \mathrm{abc}$ & $\begin{array}{l}5.33 \pm 0.20 \\
a b c\end{array}$ & $5.66 \mathrm{ab}$ & $\begin{array}{l}8.76 \pm 0.38 \\
\mathrm{a}\end{array}$ & $\begin{array}{l}6.83 \pm 0.31 \\
b\end{array}$ & $7.8 \mathrm{a}$ \\
\hline $\begin{array}{l}\text { Only upper and side } \\
\text { white net }\end{array}$ & $\begin{array}{l}24.66 \pm \\
1.09 c\end{array}$ & $\begin{array}{l}25.66 \pm \\
1.08 c\end{array}$ & $25.16 \mathrm{c}$ & $\begin{array}{l}7.33 \pm 0.31 \\
\mathrm{a}\end{array}$ & $\begin{array}{l}6.66 \pm 0.30 \\
a b\end{array}$ & $7.0 \mathrm{a}$ & $\begin{array}{l}8.63 \pm 0.33 \\
\mathrm{a}\end{array}$ & $\begin{array}{l}7.20 \pm 0.31 \\
\mathrm{ab}\end{array}$ & $7.91 \mathrm{a}$ \\
\hline $\begin{array}{l}\text { under both green } \\
\text { and white net }\end{array}$ & $\begin{array}{l}33.66 \pm \\
1.11 \mathrm{a}\end{array}$ & $\begin{array}{l}35.33 \pm \\
1.06 \mathrm{a}\end{array}$ & $34.5 \mathrm{a}$ & $\begin{array}{l}4.33 \pm 0.20 \\
b c\end{array}$ & $\begin{array}{l}3.66 \pm 0.14 \\
c\end{array}$ & $4 \mathrm{~b}$ & $3.8 \pm 0.16 c$ & $3.4 \pm 0.11 c$ & $3.6 \mathrm{c}$ \\
\hline Mean $(V)$ & $29.58 \mathrm{a}$ & $28.08 \mathrm{a}$ & & $5.58 \mathrm{a}$ & $5.0 \mathrm{a}$ & & $6.89 \mathrm{a}$ & $5.78 \mathrm{~b}$ & \\
\hline
\end{tabular}

Table 2: Impact of varieties and treatments on days to shifting, rooted cutting \% and callused cutting \%.

\begin{tabular}{|c|c|c|c|c|c|c|}
\hline \multirow[t]{3}{*}{ Treatments } & \multicolumn{3}{|c|}{ Rooted cutting \% } & \multicolumn{3}{|c|}{ Callused cutting \% } \\
\hline & \multicolumn{2}{|l|}{ Varieties V XT } & \multirow{2}{*}{$\begin{array}{l}\text { Mean } \\
(\mathrm{T})\end{array}$} & \multicolumn{2}{|l|}{ Varieties VXT } & \multirow{2}{*}{$\begin{array}{l}\text { Mean } \\
(\mathrm{T})\end{array}$} \\
\hline & Coratina & Frantoio & & Coratina & Frantoio & \\
\hline Only green net & $41.74 \mathrm{a}$ & $17.84 \mathrm{c}$ & $29.79 \mathrm{~b}$ & $7.65 \mathrm{ab}$ & $2.37 \mathrm{c}$ & $5.01 \mathrm{ab}$ \\
\hline Only white net & $28.08 \pm 1.40 \mathrm{~b}$ & $24.38 \pm 1.21 \mathrm{bc}$ & $26.23 \mathrm{~b}$ & $8.51 \pm 0.42 \mathrm{ab}$ & $3.34 \pm 0.16 \mathrm{c}$ & $5.92 \mathrm{ab}$ \\
\hline Only upper and side white net & $44.85 \pm 2.24 \mathrm{a}$ & $31.43 \pm 1.57 \mathrm{~b}$ & $38.14 \mathrm{a}$ & $5.04 \pm 0.25 b c$ & $2.66 \pm 0.13 c$ & $3.85 \mathrm{~b}$ \\
\hline under both green and white net & $31.42 \pm 1.57 \mathrm{~b}$ & $26.73 \pm 1.33 \mathrm{~b}$ & $29.07 \mathrm{~b}$ & $9.38 \pm 0.46 \mathrm{a}$ & $5.67 \pm 0.28 \mathrm{bc}$ & $7.52 \mathrm{a}$ \\
\hline Mean (V) & $36.52 \mathrm{a}$ & $25.09 \mathrm{~b}$ & & $7.64 \mathrm{a}$ & $3.51 \mathrm{~b}$ & \\
\hline
\end{tabular}

the same variety $(8.63 \mathrm{~cm})$ under $T_{3}$. The treatment $\mathrm{T}_{4}$ resulted from poor root length and was found at the bottom regarding both varieties.

\section{Rooted cutting\%}

After 7 weeks from cutting plantation, the majority of cuttings were callused or rooted (Table 2). The higher and lower light intensities $\left(\mathrm{T}_{2} \& \mathrm{~T}_{4}\right)$ treatments had the highest fraction of mortality, whereas both varieties showed different behavior under lower and higher regimes. A statistically significant difference was found in both varieties under all treatments (Table 2). In comparison of performance between varieties, Coratina performed better under low light intensity $\mathrm{T}_{1}(41.74 \%)$ \& higher light intensity $\mathrm{T}_{2}(31.42 \%)$ as compared to variety Frantoio (17.84 \%) \& (24.38 \%) respectively. The results depicted that variety Coratina was found more resistant to higher and lower light intensities than variety Frantoio. However, both the varieties have non-significant variation at the light intensity under $\left(\mathrm{T}_{3}\right)$. The minimum rooted cutting percentage was recorded in variety Frantoio (17.84 \%) under only green net treatment (5538 lux).

\section{Callused Cutting \%}

It was noted that statistically significant variation was found in varieties, treatments, and interaction between varieties and treatments (Table 2). The maximum callused cutting \% (7.5\%) was observed under $\mathrm{T}_{4}$ treatment followed $\mathrm{T}_{2}$ while minimum (3.85\%) callused cutting percentage was recorded under $\mathrm{T}_{3}$. The findings of interaction between varieties and treatments indicated that maximum callused cutting $\%$ was recorded in variety Coratina $(9.38 \%)$ under low light intensities treatments $\mathrm{T}_{4}(5538 \mathrm{lux})$ and $\mathrm{T}_{1}$ (5944 lux) while the minimum callused cutting \% was recorded in variety Frantoio $(2.37 \%)$ under $\mathrm{T}_{1}(5944$ lux) treatment. Overall it could be concluded that under low-intensity root initiation will take more time with higher callus formation.

Light intensity is an important phenomenon for the successful propagation of rooted cuttings. The complementary effects of light intensities on the propagation of many plants species were well described (Currey et al., 2012; Lopez and Runkle, 2008; Park et al., 2011; Zobolo, 2010). The results of the above-mentioned studies showed that light intensity plays an important role in photosynthesis up to the optimum level. It was observed that excessive light intensity increased the vapor pressure deficit (VPD) surrounding the cutting environment that ultimately caused the leaf dehydration in leafy cuttings while the moderate light regimes increased the photosynthetic activity. 
The high intensity is considered harmful for cuttings, as it increases the transpiration and temperature of the leaf and facilitates leaf drying. The roots of many woody and herbaceous species are affected due to high light (Aminah et al., 1997; Zaczek et al., 1997; Zobolo, 2010). We have found a positive correlation between the high light intensities with the number of roots and length which were also confirmed by other scientists. (Currey et al., 2012, Lopez and Runkle, 2008; Park et al., 2011).

The light intensity is kept low in the greenhouse usually to minimize the leaf transpiration and burning effects. The leaf photosynthesis in cuttings can play a crucial role in the formation of roots by providing the food through carbohydrates where it required rooting development for several weeks. Environmental conditions surrounding the roots are crucial for successful rooting In particular; leaf temperature and air VPD play a pivotal role in leaf survival and activity (Hartmann and Kester, 1983). Optimization of mist apparatus and spray intervals can help to counterbalance undesired VPD increase caused by greater light regimes. It is generally recommended that the light intensity should be kept low for the rooting of vegetative cuttings to minimize the leaf wilting and we observed that over light intensity hampers the rooting process. Our results were in harmony with the study of Tombesi et al. (2015) who reported that higher light intensity increased leaf wilting which resulted from poor root formation.

Olive cultivation was other than Mediterranean countries gaining popularity, especially in Pakistan. The yield and oil quality were found better (Ali et al., 2020; Iqbal et al., 2019). The study on propagation was very limited especially the impact of light intensity under greenhouse conditions. So it was tried to find out the appropriate light intensity for successful olive propagation through semi-hardwood cuttings. We have found that lower light intensity resulted from more callus formation and higher light caused a higher mortality ratio as in most of the areas in Pakistan we received higher light intensities.

\section{Conclusion and Recommendations}

It could be concluded from this study that light intensity 8000 to 8500 lux is most suitable for the sucessful ropagation of olive semi-hardwood cuttings. However, we also observed that other management factors like misting, humidity, fluctuation of light, and varieties selection have a vital impact on final success for olive propagation. Therefore, it is suggested that experiments may be conducted upon more varieties, types of cuttings, and time of planting under greenhouse conditions with optimum light intensity.

\section{Novelty Statement}

Olive is a hard to root woody plant species which is propagated through cuttings under conventional screen house. This resulted in very limited rooting success. Therefore, this study was conducted to determine the optimum level of light intensity for appropriate rooting under greenhouse conditions. Resultantly, light intensity of 8000 to 8500 lux was proved as most suitable for successful propagation of olive semi-hardwood cuttings.

\section{Author's Contribution}

Muhammad Rafique: Overall management of the article.

Muhammad Azhar Iqbal: Conceived the idea, wrote abstract and methodology.

Inam U1 Haq: Data entry, analysis and technical input at every step.

Muhammad Ramzan Anser: Introduction and references.

Humara Umar: Collected data, result and discussion. Muhammad Ashraf Sumrah: Conclusion and reviewed literature.

\section{References}

Ahmed, M., M.H. Laghari, I. Ahmed, and K.M. Khokhar. 2002. Seasonal variation in rooting of leafy olive cuttings. Asian J.Plant Sci.1:228-229. https://doi.org/10.3923/ajps.2002.228.229

Ali, M.H., Ahmad, W. and Usman, M. 2019. Rooting ability of different olive cultivars through cuttings in a basal heating system. Int. J. Res. Scho. 3(2).

Aminah,H.,Dick,J.M. and Grace,J.1997.Influence of irradiance on water relations and carbon flux during rooting of Shorealeprosula leafy stem cuttings. Tree Physiol. 17(7): 445-452. https:// doi.org/10.1093/treephys/17.7.445

Anonymous. 2018. http://parc.gov.pk/index.php/ en/olive-achievements

AslMoshtaghi, E. and Shahsavar, A.R. 2011. The 
Effects of IBA and $\mathrm{H}_{2} \mathrm{O}_{2}$ on rooting of 2 olive cultivars. J. Chem. Health Risks. 1(1).

Awan, A.A., A. Iqbal, M.J. Rehman and G. Idris. 2003. Response of olive hardwood cuttings to different growth media and basal injuries for propagation. Asian J. Plant Sci. 2: 883-886. https://doi.org/10.3923/ajps.2003.883.886

Currey, C.J., Hutchinson, V.A. and Lopez, R.G. 2012. The growth, morphology and quality of rooted cuttings of several herbaceous annual bedding plants are influenced by photosynthetic daily light integral during root development. Hort. Sci. 47(1): 25-30. https:// doi.org/10.21273/HORTSCI.47.1.25

Dvin, S.R., E.G. Moghadam, E. Neyestani and A. Mokhtarian. 2011. Studies on rooting of apple cutting using indolebutyric acid and media. Asian J. Appl. Sci. 4: 780-786. https://doi. org/10.3923/ajaps.2011.780.786

Hartmann, H.T., D.E. Kester, F.T. Davies and J.R. Genev. 2002. Plant Propagation: Principle and Practices. 7th Edn., Prentice-Hall, Upper Saddle River, New Jersey, Pages: 880.

Hartmann, H.T. and Kester, D.E. 1983. Plant Propagation Principles and Practices, $4^{\text {th }}$ Edn. Upper Saddle River, NJ: Prentice-Hall

Hussain, K., Qadri, R., Akram, M.T., Nisar, N., Iqbal, A., Yang, Y. and Iqbal, M.A. 2020. Clonal propagation of olive (Olea europea L.) through semi-hardwood cuttings using IBA under shaded polyethylene tunnels (spots). Fresenius Environmental Bulletin. 29: 8131-8137.

Iqbal, M.A., Hafiz, I. A., Abbasi, N.A. and Shah, M. K. N. 2019a. Adaptability, agronomic, and yield performance of exotic olive (Olea europaea) cultivars in the Pothwar region of Pakistan. Pak. J. Bot. 51(5): 1745-1751. https:// doi.org/10.30848/PJB2019-5(7)

Iqbal, M.A., Hafiz, I.A., Abbasi, N.A. and Shah, K.N. 2019b. Morphological, phenological characterization, and adaptability of exotic olive cultivars in district Chakwal, Pakistan. Pak. J. Agric. Sci. 56(3).

Isfendiyaroglu, M., E. Ozeker and S. Baser. 2009. Rooting of Ayvalik olive cuttings in different media. Spanish J. Agric. Res. 7: 165172. https://doi.org/10.5424/sjar/2009071-408 Lopez, R.G. and Runkle, E.S.2008. Photosynthetic dailylight integral during propagation influences rooting and growth of cuttings and subsequent development of New Guinea impatiens and petunia. Hort. Sci. 43(7): 2052-2059. https:// doi.org/10.21273/HORTSCI.43.7.2052

Loreti, F. and H.T. Hartmann. 1964. Propagation of olive trees by rooting leafy cuttings under mist. J. Am. Soc. Hort. Sci. 85: 257-264.

Mehri, H. 2009. The current state of the Saudi Arabian olive sector and its future development. Proceedings of the 14th Scientific-Technical Symposium, May 13-15, 2009, Jaen, Spain

Park,S.M.,Won,E.J.,Park,Y.G.andJeong,B.R.2011. Effects of node position, number of leaflets left, and light intensity during cutting propagation on rooting and subsequent growth of domestic roses. Horti. Environ. Biotech. 52(4): 339. https://doi.org/10.1007/s13580-011-0163-z

Rehman, R.U., Shah, A.H., Awan, A.A. and Ali, H. 2013. Response of olive cultivars to rooting through air layering in different growth media. Sarhad J. Agric. 29(1): 1-5.

Sebastiani, L. and R. Tognetti. 2004. Growing season and hydrogen peroxide effects on root induction and development in Olea europaea L. (CVs Frantoio and Gentile di Larino) cuttings. Sci.Hort.100: 75-82.https://doi.org/10.1016/j. scienta.2003.08.008

Seyhan, O. and O. Gezerel. 2005. The Effects of the different doses of IBA (Indol butyric acid) on the rooting performances in the reproduction of "Gemlik" and "Domat" olive trees by using the green twig procedure in the ecology of the cukurova region. Central Eur. J. Agric. 6(4): 481-484.

Tombesi, S., Palliotti, A., Poni, S. and Farinelli, D. 2015. Influence of light and shoot development stage on leaf photosynthesis and carbohydrate status during the adventitious root formation in cuttings of Corylusavellana L. Front. plant sci. 6: 973. https://doi.org/10.3389/fpls.2015.00973

Turkoglu, N. and M. Durmus.2005. A study on root formation of four olive varieties by application of hormone. Asian J. Plant Sci. 4: 455-457. https://doi.org/10.3923/ajps.2005.455.457

Zaczek, J.J., HeuserJr, C.W. and Steiner, K.C. 1997. Effect of shade levels and IBA during the rooting of eight tree taxa. J. Environ. Horti. 15(1): 56-60. https://doi.org/10.24266/0738-289815.1 .56

Zobolo, A.M. 2010. Effect of temperature, light intensity, and growth regulators on the propagation of Ansellia Africana from cuttings. Afr. J. Biotechnol. 9(34). 